\title{
[ 小特集星
}

\section{5. 衛星放送家庭用受信機の現状}

\author{
正会員 仁 尾 浩 - $^{\dagger}$, 星 野 紀 甫 ${ }^{\dagger}$
}

\section{1. ま え がき}

$12 \mathrm{GHz}$ 帯での低価格な低雑音受信機の開発が望ま れて以来 10 年が経過したが, この間の半導体素子を 初めとするマイクロ波技術の進歩は著しい。特に，低 雑音受信の心臓ともいうべき GaAs FET の発達はす ばらしく, 雑音特性のみならず価格面においても家庭 用受信機として使用が充分可能となっている. 実際, 現在市販されている家庭用受信機には、このFET を 用いた低雑音前置増幅器が組み込まれており, その特 性も $70 \mathrm{~cm}$ 前後のパラボラアンテナで良好な受信が できる低雑音性を有している.

ところで, 衛星放送を受信技術の立場で見たとき，

（1）降雨による受信電力の減衰が無視できない

（2）映像が FM, 音声がディジタル伝送される

（3）地上放送用受信設備との整合が必要

（4）今後の新サービスへの拡張性の確保

など, 従来の VHFやUHF 帯でのテレビ放送では経 験しない新しい特長が多く, 家庭用受信機の機能や性 能は, 高感度, 高品質に加えて上記の技術的特長を充 分考慮したものでなくてはならない。一般に家庭用受 信機は，性能に重きを置いた高級機から低価格性を実 現した普及機まで幅広い製品が市販されており，こう した幅の広さは製品の品質向上と放送の普及を促進し ているのも事実である．衛星放送用受信機も，家電機 器としての自由度を有していて画一的に性能や機能を 規定することは困難であろう。しかし，その反面，受 信機の多様な使用状況を考え，また衛星放送の普及促 進と将来の発展を考えるとき, 最小限の規定されるべ き性能項目もある。

本稿では, BS-2 システムを例にとり衛星放送を受

$\dagger$ NHK 放送技術研究所

"5. Present Status of Home-Receivers for Satellite Broadcasting" by Koichi Nio and Norio Hoshino (NHK Science and Technical Research Laboratories, Tokyo)
信サイドから眺めてその特長を述べるとともに，特に 重要な性能項目についての技術的背景と, 市販受信機 の現状について紹介する，なお，受信機を構成する回 路技術については，平田らによる紹介 ${ }^{11}$ があるので参 考にされたい。

\section{2. 衛星放送用受信機の性能}

\section{1 受信品質と受信設備}

テレビジョンの衛星放送では受信品質として，5段 階画像評価での評価 4 以上（専門家による）を目標に おいている. 図 1 は受信端における $\mathrm{CN}$ 比と受信品 質との関係を示したもので, 上記品質を維持するため には CN 比は $14 \mathrm{~dB}$ 以上が必要になる.図では受信 電力が低下して $\mathrm{CN}$ 比が $9 \mathrm{~dB}$ 以下になると画質が急 激に劣化することが示され，FM 伝送方式の特長があ らわれている。

$\mathrm{CN}$ 比は, 衛星送信電力, 送信アンテナ利得などの 送信条件と地上受信設備の性能によって決まるほか, 降雨による伝搬特性減衰の影響を受ける。図 2 は, 全 国平均に近い東京地域での降雨減衰と最悪月時間率と の関係を示したものである ${ }^{2)}$. 所定の受信品質が維持

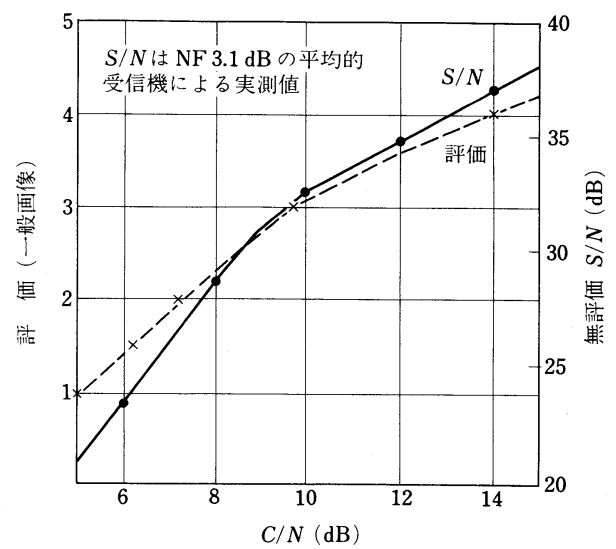

図 $1 \mathrm{CN}$ 比と受信画質

テレビジョン学会誌 Vol. 38, No. 10 (1984) 


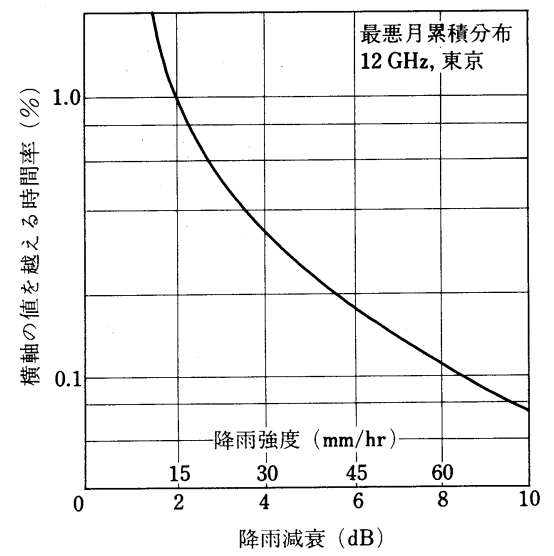

図 2 推定降雨減衰值

できる時間率が大きい方が望ましいが，受信設備 の負担も考慮して衛星放送では $99 \%$ の時間率を 目標においている。したがって，全国平均でみた 降雨減衰量としては $2 \mathrm{~dB}$ を見込んでおく必要が あることになる。なお, 図 1 , 図 2 から降雨減衰が大 きくなり受信画質が評価 2 以下に低下する場合もある ことがわかる．その発生時間率は極めて小さいもの の, 従来の地上放送にはない新しい経験といえる.

BS-2 での送信アンテナ利得 $G_{T}$ の分布は本小特集 第 1 章の図 2 に示されている.

また, 図 3 は, $\mathrm{CN}$ 比 $14 \mathrm{~dB}$ を得るのに必要な受信 機雑音指数 NF と受信パラボラアンテナの直径との 関係を示したものである. 衛星放送システム検討に際 しては多くの場合, 受信アンテナの効率 $\eta$ を $55 \%$ と している。最近ではオフセット方式の採用などにより $65 \%$ 前後の効率が得られており, NFの進歩もあっ て, 図のように送信ビームの中心附近では $60 \mathrm{~cm}$, 本 州の大部分の地域で $75 \mathrm{~cm}$ 程度の直径で良いといえ る。

\section{2 受信機の性能}

家庭用として望ましい受信機の定格, 性能および, その試験方法についての総合的な調查研究が行われ $た^{32 \sim 5)}$. 調査結果は, “目標定格”, “望ましい性能” としてまとめられていて必ずしも市販受信機を規制す るものではないが, 高性能化と量産性との整合をはか りつつ家庭用としての望ましい形態を求めたもので, 受信機の設計開発に大きな指針を与えている. 詳細は 同報告書を参照して頂くとして, 特に重要な 2 点につ いて説明する。

（1）干渉に対する配慮

干渉に関して特に重要なのは第 1 , 第 2 両中間周波 数の選定である. 特に第 1 中間周波数については, そ

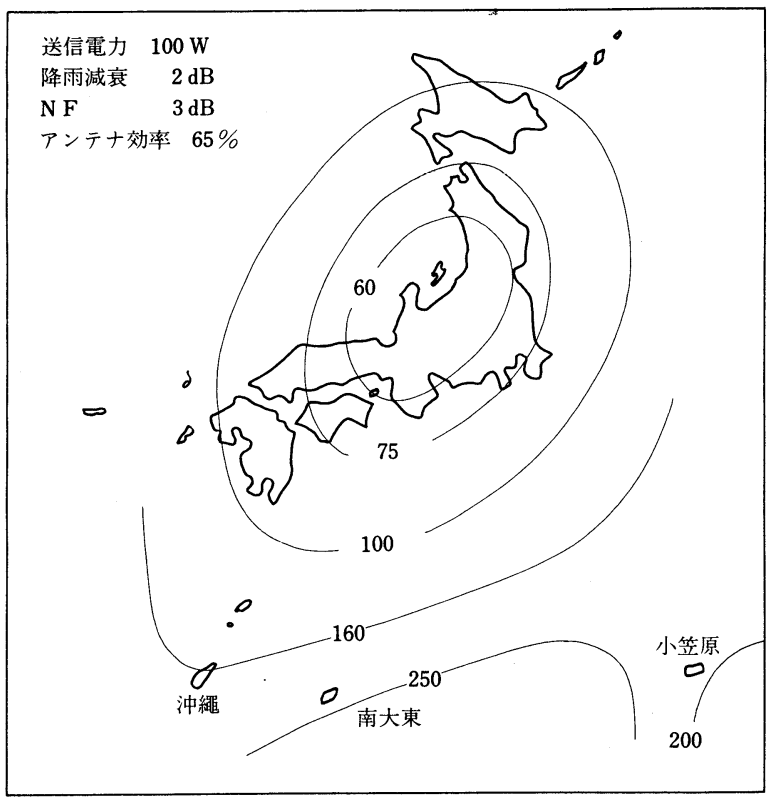

図 3 BS-2 で CN 比 $14 \mathrm{~dB}$ (最悪月 99\%) を得るに必 要なアンテナ直径

の局部発振の漏れ電力がアンテナから放射されて他の 通信に妨害を与える恐れがある。このため，電波管理 上の立場から昭和 56 年度の電波技術審議会において 局部発振周波数が検討され，電波天文等の宇宙業務や FPU 業務に割り当てられている周波数帯を避けて, $10.678 \mathrm{GHz}$ (許容偏差は $+2 \mathrm{MHz},-3 \mathrm{MHz}$ ) が答申 されている.この結果, 第 1 中間周波数は $1 \sim 1.3$ $\mathrm{GHz}$ と比較的高い值となる.

第 2 中間周波数は, その局部発振の漏れ電力が直接 空中に放射されないため比較的自由に選び得る．通常 は, 大電力送信局に割り当てられている周波数を避け て $130 \mathrm{MHz}$ や $400 \mathrm{MHz}$ が用いられる. 個別受信用 受信機であっても, ホーム共聴など 1 台の BS コンバ ーターに複数の BS チューナーを接続する場合があ り，その場合，第 2 局部発振の漏れ電力が相手方のチ ューナーに混入し干渉を生じる恐れがある。

第 2 中間周波数として $134.26 \mathrm{MHz}$ または 402.78 $\mathrm{MHz}$ が選ばれているのも, こうした干渉を避けるた めであって, 第 2 局部発振周波数がチャンネルとチャ ンネルの中間にくるような周波数関係になっている.

\section{（2）互換性に対する配慮}

衛星放送受信機を構成する各ユニットは必ずしも同 一メーカーで一貫して製造販売されるとは限らない. 各ユニット間の互換性を確保しておくことは, 製造上 のみならず使用上からも重要である. 前述の定格, 性 能においては受信機を, 1 次放射器を含めたアンテナ 


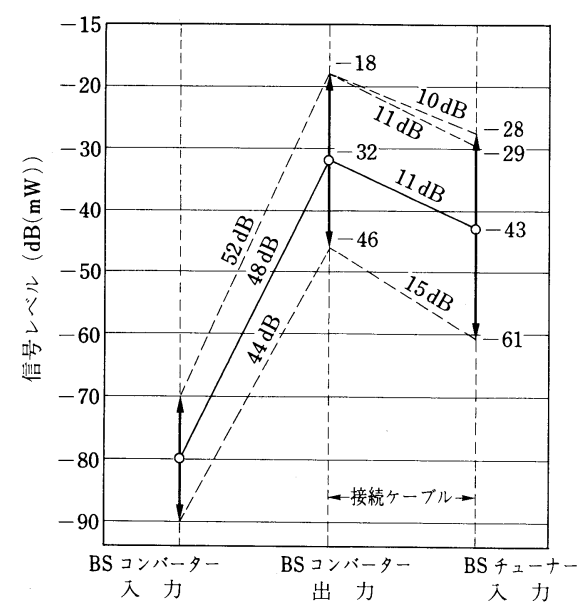

図 4 BS コンバーター入力から BS チューナー入力 までの信号レベルダイヤグラム

部, BS コンバーター, 中間接続ケーブルおよび BS チューナーの 4 ユニットに分け, その各々の分割点に おいて電気的・機械的接続条件が明確にされている.

図 4 は，各接続点での高周波信号受け渡しレベルを 示したもので, BS コンバーター入力端においては将 来の送信電力増加や受信アンテナ利得増加を見込ん で土10 dB のダイナミックレンジを確保してある。ま た, コンバーター利得は 8 チャンネル同時受信時の混 変調を考慮して定められている.コンバーターとチュ 一ナー間の接続ケーブル長は, 日本家屋の大きさ等を 考慮して 10,20，30 m の 3 種類の長さを標準とし， チューナー入力レベルは最小受信レベルに扔いても充 分な受信品質が得られる值となっている.

\section{3. 受信 方 法}

衛星放送の受信には，天空が見通せる場所を選び， パラボラアンテナを正しく衛星位置に向けて設置する 必要がある。この時, 強風時には高い風圧を受けるた め地面や建造物に強固に取り付ける必要があり, 設置 状態に応じた工事方法が定められている ${ }^{6)}$.

個別受信の場合は，BS チューナーの出力を既存の 地上放送用受像機の入力端子 (AV 形テレビではビデ オ入力端子, $\mathrm{RF}$ 入力のみの受像機では $\mathrm{UHF}$ 帯第 13 チャンネル）に接続すれば良い。アパートなどの集合 住宅や共同受信の場合，既設の共聴設備に衛星放送の 受信波を導入する必要がある. $1 \mathrm{GHz}$ の第 1 中間周 波数をそのまま重畳できれば良いが，多くの場合既設 設備は地上放送を対象としており, 伝送可能な周波数 はVHFまたは UHF 帯である。このため, 衛星受信 信号を地上放送と同じ $\mathrm{AM}$ 波に再変調し, その地域
の空きチャンネルを使って分配する方法が考えられて いる. 比較的適用範囲が広く, また受信者の負担は少 いが, 衛星放送の高画質性や PCM 音声伝送の特長は 失われる.今後建設されるビル共聴などでは, $1 \mathrm{GHz}$ 帯伝送が可能な設備を導入することが望まれる。

\section{4. 市販受信機の現状}

衛星放送受信機は，受信アンテナ，BS コンバータ 一, BS チューナーから構成され，現在国内の家電お よび共聴メーカー十数社から一般に市販されている。 これらの受信機は，2節で述べた定格および性能に沿 って設計されている.

また，BS-IF 帯伝送抢よび UHF (FM) 伝送の共同 受信システムに使用する共聴用機器も衛星放送 CATV 技術調査会で検討された性能》をもとに製作 され, 共聴機器メーカーから市販されている.

ここでは, 市販されている受信機および共聴機器の 主な点について概説する。

\section{1 受信機}

各メーカーのBS コンバーターと BSチューナー は, 定格で電気および機械的な互換性がとられている ため，ユーザー側で自由に組み合せができる．

BS チューナーには，映像および音声アナログ信号 (最低，ステレオ用 2 端子）の出力端子と RF-AM 再 変調器出力端子があるため, AV 形テレビまたは, $\mathrm{RF}$ 端子のみの受信機に接続が可能である.

以下，各ユニット毎に説明する。

(1) 受信アンテナ

直径 $120 \mathrm{~cm}$ 以下の市販受信アンテナは，すべてオ フセット形のパラボラアンテナである．この理由は， 小口径のセンターフィード形パラボラアンテナの 1 次 放射器で生じるブロッキングの解消とサイドローブの 軽減で開口効率を向上し，アンテナの小形化をはかる ためである。

この場合， 1 次放射器による反射鏡面上への電界の 照射分布の不均一を改善するため, $f / D$ を大きくし (0.47〜0.57) 反射鏡面を平板に近くしたり，副ホーン を付加するなどの工夫がされている.

また，円偏波受信に対する偏波損の改善として副乇 ードホーンを採用したものや, 簡単な構造で円偏波/ 直線偏波変換器が不用なへリカル形 1 次放射器を用い たアンテナなどもある.

以上のような種々の工夫により, 市販受信アンテナ の開口面効率は, 約 $65 \%$ 程度に改善されている。こ のことは, 従来の簡易形パラボラアンテナの開口面効 率約 $50 \%$ と比較すると, オフセット形であるための 
反射板面積の増加はあるものの効率改善効果が大きく アンテナ面積で約 10\%小形化されたことになる.

市販受信アンテナには FRP 材が多く使用されてい る.この理由は, オフセット形のような回転対称でな い形状のものを自由に加工成形でき, 鉄よりも強く, アルミよりも軽いことから, 量産性に富み, 寸法精度 が高く，安価なアンテナが期待できることにある．

FRP 材を用いたアンテナは, FRP 表面にアルミ蒸 着を施すか, アルミメッシュまたはアルミ箔が FRP でサンドイッチされている.また，金属部分をもた ず，カーボン繊維の比抵抗差を利用した反射鏡もあ る.

\section{（2）BS コンバーター}

低雑音が要求される BS コンバーターには, 12 $\mathrm{GHz}$ 帯の GaAs FET 増幅器がミキサー前段に挿入さ れている.この前置増幅器の利得が高ければ, ミキサ 一以降の雑音指数は無視できるので, 市販 BS コンバ ーターの前置増幅器は，2段または， 2 段を 1 ブロッ クとした 2 ブロック（4 石）で構成されている.

前置増幅器, ミキサーおよび局部発振器の各回路 は, $0.6 \sim 0.8 \mathrm{~mm}$ 厚のテフロングラス基板 $\left(\varepsilon_{r} \fallingdotseq 2.3\right)$ による MIC を採用している.テフロン基板を用いて いる理由は, 回路の低損失化および製作の容易性を考 慮したためである.

通常, 2 段の低雑音増幅器は, 初段を雑音整合, 次 段を利得整合として設計される。しかし，雑音整合イ ンピーダンスと入カインピーダンス（複素共役インピ ーダンス）の違いによる入力 VSWR の劣化を極力抑 える目的で，準雑音整合の設計をしたものもある.

市販 BS コンバーターの雑音指数は，メーカーによ る回路構成, 使用半導体の違いや, 素子のばらつきな どを考えると, 現在約 $2.4 \sim 3.2 \mathrm{~dB}$ 程度と見てよ い.

局部発振器には, GaAs FET と誘電体共振器を組 み合せた $10 \mathrm{GHz}$ 帯直接発振方式が採用されている。
周囲温度の変化による発振周波数の変動は, 使用す る誘電体共振器の $Q$ 值および誘電率の温度係数によ って決定される．現在，各社が使用している誘電体材 料の特性は, 無負荷 $Q$ 值が $5000 \sim 10000$, 誘電率の 温度係数が数 $\mathrm{ppm} /{ }^{\circ} \mathrm{C}$ 程度で，この材料を用いて局部 発振器を構成すると, $-30 \sim+50^{\circ} \mathrm{C}$ 温度範囲にお いて $\pm 1 \mathrm{MHz}$ 以内の周波数安定度が得られる。

$\mathrm{BS}$ コンバーターの消費電力は約 $2.5 \sim 3.3 \mathrm{~W}$ 程度 である.

（3）BSチューナー

市販 BS チューナーの回路構成は，使用する第 2 中 間周波数によって $2 つ の$ 形式に分けられる.

現在，第 2 中間周波数は暫定的に $134.26 \mathrm{MHz}$ も しくは $402.78 \mathrm{MHz}$ の 2 つ周波数帯に決められて いるため, 市販されている BS チューナーも，ほぼ同 じ割合いで両者の周波数が使われている.

BS チューナーの入力から FM 検波までの代表的な 回路構成例を図 5 に示す.

第 2 中間周波数を $130 \mathrm{MHz}$ 帯とした場合, 衛星放 送の受信帯域が $300 \mathrm{MHz}$ あるため, 受信帯域の一部 がイメージ周波数となる。 そこで，イメージ妨害を避 けるため, BS チューナーの入力部に可変 BPF (約 50 $\mathrm{MHz}$ 帯域) を插入したチューナー方式が使用されて いる.

チャンネル選択を行う第 2 中間周波数段の BPF は 小形, 量産に適し, 帯域外減衰量と帯域内遅延特性の 優れた SAW フィルターである。この SAW フィルタ 一により，隣々接チャンネルの信号は, $40 \mathrm{~dB}$ 以上抑 圧される. FM 検波回路は, 通常の複同調形 $\mathrm{FM}$ 検 波器が多く使用されている.

一方, 第 2 中間周波数を $400 \mathrm{MHz}$ 帯とした場合, イメージ周波数は受信帯域外となるため, 入力部には $300 \mathrm{MHz}$ 帯域の固定 BPF を挿入すればよい.

第 2 中間周波数段の BPFには, ヘリカル形のフィ ルターが多く使用されている。このフィルターは，へ

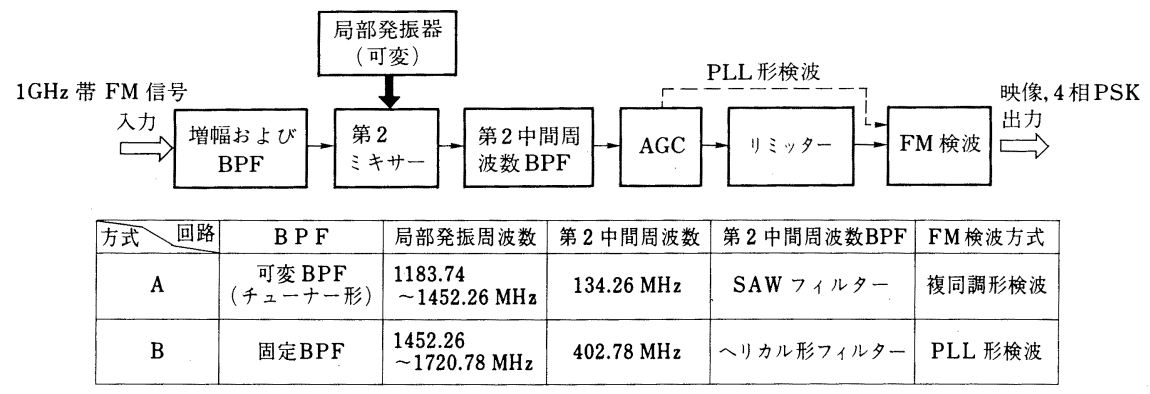

図 5 代表的な BS チューナーの回路構成例 
リカル共振器を 3 段結合したもので, 隣々接妨害を避 けるため, バッファアンプを介して 2 つ插入するか， もしくはノッチフィルターと併用する方式がとられて いる。

$\mathrm{FM}$ 検波器には, スレッショルドレベルの改善をは かる目的で, PLL形の検波方式が多く使われてい る。

この方式によると, 従来のスタティックスレッショ ルドレベルを約 $4 \sim 5 \mathrm{~dB}$ 程度改善できる. しかし, カラーバー信号のような飽和レベルに近い信号では, 変調諸元の関係から $1 \sim 2 \mathrm{~dB}$ の改善しか望めない. これに関しては, 新しい技術の開発が必要である。

PCM 音声復調回路の構成を図 6 に示す. 図に示す ように, 映像・音声副搬送波分離回路により分離され た $5.73 \mathrm{MHz}$ の 4 相 PSK 変調信号は, 約帯域 1 $\mathrm{MHz}$ の BPF, PSK 復調器を通り, ディジタル信号に 再生される. PCM 信号処理回路では, デスクランブ ル, デインターリーブ, エラー訂正, 補正などが行わ れ, その後, D/A 変換器でアナログ信号に変換され る。

現在, これらの回路は国内数社により IC および LSI 化されている. 各社の IC/LSI 構成には若干の設 計思想の違いが見られるが ${ }^{899}$, 概略, 4 相 PSK 復調 用に 1 個の IC, PCM 信号処理回路用に 2 4 個の LSI, D/A 変換用に 2 個の IC，おょび $4 \mathrm{~K}$ のスタテ イック RAM が, PCM 音声復調回路として使用され ている.

以上, 市販されている衛星放送用受信機について, その現状を述べたが, 主な構成および特性例を市販受 信機のカタログから抜粋し, まとめたものを表 1 に示 す.

\section{2 共聴用機器}

$\mathrm{BS}$ コンバーターの第 1 中間周波数である $1.3 \mathrm{GHz}$ 帯の FM 信号をケーブル分配する共同受信システム
に使用される主な共聴機器には, 分配器, 分岐器, 直 列ユニット, 増幅器, BS・UV 分波混合器などがあ る。また，既存の UHF 共同受信システムに，FM 信 号を，そのまま分配するためには，ダウンコンバー夕 一およびアップコンバーターなどの機器が必要であ る.

このような各種機器において特に重要な性能項目に は, 入出力VSWR, 振幅および位相の周波数特性, 増幅器の直線性がある。例えば，ケーブルで接続され た各機器の VSWR が劣化すると, 各機器間で反射波 による振幅および位相ひずみが起こる.

このひずみを受けた信号は, DG および DP の劣化 をはじめ, エネルギー拡散信号によるフリッカーを生 じる.このため, 反射波の DU 比と妨害の検知限を 主観評価によって求め ${ }^{10)}$, 各機器の入出力 VSWR が 表 2 のように決められている.

また, 各機器のVSWR は, 使用するコネクターの VSWR も関係することから，第 1 中間周波数である $1.3 \mathrm{GHz}$ において低 VSWR のコネクターも開発され ている（日本電子機械工業会技術基準 RCZ-6015, 高 周波同軸 C 15 形コネクター).

伝送系に用いる増幅器の非直線ひずみによる相互変 調妨害は, 加入者端子で検知限になる DU 比 $31 \mathrm{~dB}$ 以上の值とし, 伝送チャンネルおよび増幅器接続段数 による, それぞれの相互変調量が決められている7). これを表 3 に示す。

UHF 共同受信システムに衛星放送を伝送する場 合, ダウンコンバーターおよびアップコンバーターが 必要である.この場合, コンバーターに使用される局 部発振器の周波数変動が重要となる. BS チューナー

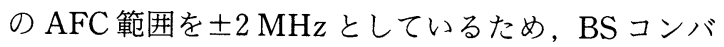
ーターの周波数漂動と合せて，上記アップおよびダウ ンコンバーターの周波数漂動は, それぞれ 0.5 $\mathrm{MHz}$ となっている.

誤り検出

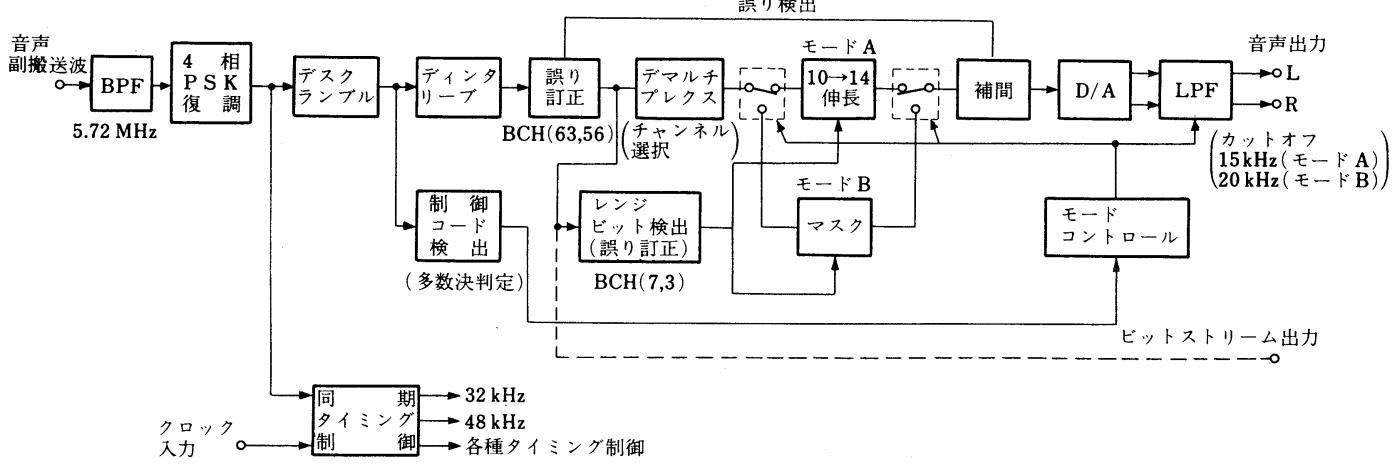

図 6 PCM 音声復調回路構成 
表 1 市販受信機の構成と特性例 (国内十数社のカタログから抜粋)

\begin{tabular}{|c|c|c|c|c|c|c|c|c|c|}
\hline $\begin{array}{l}\text { 機器と } \\
\text { 項目 }\end{array}$ & & ン $\quad \bar{T}$ & & B S コン & シーター & & B S fュ & ーナー & \\
\hline xーカー & 構 造 & 材 質 & 効 率 & 前段構成 & $\mathrm{NF}[\mathrm{dB}]$ & 第 2 IF & 検波方式 & 第 2 B P F & $\begin{array}{c}\mathrm{RF} \\
\text { 再変調器 }\end{array}$ \\
\hline A & オフセット & $\begin{array}{c}\text { F R P } \\
\text { アルミ蒸着 }\end{array}$ & $60 \%$ 以上 & $\begin{array}{c}\text { F E T } \\
2 \text { 段 }\end{array}$ & $\begin{array}{c}2.5 \text { 標準 } \\
(2.4 \sim \\
2.6 \mathrm{~dB}) \\
\end{array}$ & $402.78 \mathrm{MHz}$ & 複同調方式 & 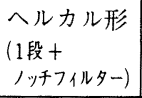 & 有 \\
\hline B & オフセット & アルミ板 & $\begin{array}{l}65 \% \text { 以上 } \\
\text { (ヘルカル形) }\end{array}$ & $\begin{array}{c}\mathrm{FET} \\
2 \text { 段 }\end{array}$ & $\begin{array}{c}3.5 \text { 以下 } \\
(2.5 \sim \\
2.8 \mathrm{~dB}) \\
\end{array}$ & $\begin{array}{c}134.26 \mathrm{MHz} \\
(\text { 入力 } \\
\text { チューナー) }\end{array}$ & 複同調方式 & SAW & 有 \\
\hline $\mathrm{C}$ & オフセット & $\begin{array}{c}\text { F R P } \\
\text { アルミメッシュ }\end{array}$ & $65 \sim 70 \%$ & $\begin{array}{c}\mathrm{FET} \\
2 \text { 段 } \\
(15 \sim 16 \mathrm{~dB}) \\
\end{array}$ & $2.3 \sim 3.4$ & $402.78 \mathrm{MHz}$ & PLL方式 & SAW & 有 \\
\hline D & オフセット & アルミ板 & $65 \%$ & $\begin{array}{c}\text { F E T } \\
2 \text { 段 } \\
(27 ゙ ロ ッ ク, 4 \text { 石 }) \\
\end{array}$ & 2.5 標準 & $402.78 \mathrm{MHz}$ & PLL方式 & $\begin{array}{l}\text { ヘリカル形 } \\
\text { (3ポール,2段) }\end{array}$ & 有 $\odot$ \\
\hline E & オフセット & $\begin{array}{c}\text { F R P } \\
\text { アルミ箔 }\end{array}$ & $\begin{array}{c}70 \sim 76 \% \\
\text { (副ホーン) }\end{array}$ & $\begin{array}{c}\text { F E T } \\
2 \mathbf{E}(16 \mathrm{~dB})\end{array}$ & 2.5 標準 & $402.78 \mathrm{MHz}$ & PLL方式 & 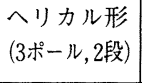 & $\odot$ \\
\hline $\mathrm{F}$ & オフセット & アルミ板 & $\begin{array}{c}70 \sim 75 \% \\
\text { (副モード } \\
\text { ホーン) }\end{array}$ & $\begin{array}{c}\text { F E T } \\
2 \text { 段 }\end{array}$ & $3.5 \sim 4.0$ & $\begin{array}{c}134.26 \mathrm{MHz} \\
\text { (大力 } \\
\text { 夭ューナー) }\end{array}$ & 複同調方式 & SAW & 有 \\
\hline G & オフセット & $\begin{array}{c}\text { F R P } \\
\text { カーボンシート }\end{array}$ & $\begin{array}{c}65 \% \\
\text { (副ホーン) }\end{array}$ & $\begin{array}{c}\text { F E T } \\
2 \text { 段 } \\
(2 \text { ブロック,4石) }\end{array}$ & $2.5 \sim 3.0$ & $\begin{array}{l}134.26 \mathrm{MHz} \\
\text { (入力 } \\
\text { チューナー) }\end{array}$ & $\begin{array}{c}\text { 複同調方式 } \\
\text { (同軸線) }\end{array}$ & SAW & $\odot$ \\
\hline
\end{tabular}

$\odot$ ステレオ対応

表 2 共聴機器の入出力 VSWR

\begin{tabular}{|c|c|c|c|c|c|c|}
\hline $\begin{array}{l}\text { 周波 } \\
\text { 数耐 }\end{array}$ & $\begin{array}{l}\text { 分 配 器 } \\
\text { (2, } 4 \text { 分配) }\end{array}$ & $\begin{array}{l}\text { 分 岐 器 } \\
(1,2,4 \text { 分岐 })\end{array}$ & 直列ユニット & BS-IF 増幅器 & $\begin{array}{l}\text { ダウ ン } \\
\text { コンバーター }\end{array}$ & $\begin{array}{l}\text { アッ プ } \\
\text { コンバーター }\end{array}$ \\
\hline V H F & 1.8以下 (1.6) & 1.8 以下 (1.6) & 1.8以下 (1.6) & \multirow[t]{3}{*}{2.5 以下 } & \multirow{3}{*}{$\begin{array}{c}2.5 \text { 以下 } \\
\text { (入力 } 1035 \sim 1335 \mathrm{MHz} \text { ) } \\
\text { (出力 } 470 \sim 765.52 \text { ) }\end{array}$} & \multirow{3}{*}{$\begin{array}{c}2.5 \text { 以下 } \\
\text { (大力 } 470 \sim 765.52 \mathrm{MHz} \text { ) } \\
\text { (出力 } 1035.98 \sim 1331.5 \text { ) }\end{array}$} \\
\hline U H F & 1.8以下 (1.6) & 1.8以下 (1.6) & 1.8以下 (1.6) & & & \\
\hline BS-IF & 2.0以下 (1.8) & 1.8以下 (1.8) & 2.0以下 (1.8) & & & \\
\hline
\end{tabular}

（）望ましい性能值，入出カインピーダンス $75 \Omega$

表 3 増幅器の相互変調

\begin{tabular}{|c|c|c|}
\hline & \multicolumn{2}{|c|}{ 伝送チャンネル数 } \\
\hline & 8 & 4 \\
\hline $\begin{array}{l}\text { 壁面端子において } \\
\text { (チャンネル当り) }\end{array}$ & $31.0 \mathrm{~dB}$ 以上 & $31.0 \mathrm{~dB}$ 以上 \\
\hline $\begin{array}{r}\text { 増 幅 器 単 体 } \\
\text { ( } 2 \text { 信 号 法) }\end{array}$ & $49.0 \mathrm{~dB}$ 以上 & $40.5 \mathrm{~dB}$ 以上 \\
\hline $\begin{array}{r}\text { 増 幅 器 単 体 } \\
\text { (2段接続用) }\end{array}$ & $55.0 \mathrm{~dB}$ 以上 & $46.5 \mathrm{~dB}$ 以上 \\
\hline $\begin{array}{r}\text { 増 幅 器 単 体 } \\
\text { (3段接続用) }\end{array}$ & $58.5 \mathrm{~dB}$ 以上 & $50.0 \mathrm{~dB}$ 以上 \\
\hline $\begin{array}{r}\text { 増 幅 器 単 体 } \\
\text { (4 段接続用) }\end{array}$ & $61.0 \mathrm{~dB}$ 以上 & $52.5 \mathrm{~dB}$ 以上 \\
\hline
\end{tabular}

以上, 共聴機器の主な点について述べたが, 各機器 の性能および規格についての詳細は，文献 7)を参照 されたい。

\section{5.む す び}

衛星放送につき, 受信サイドからみた概要と市販受 信機の現状を紹介した．

当初からの大きな課題であった低雑音特性について も，マイクロ波 FET の進歩によって実用上充分な性 能が実現している。また種々の計画検討において 55 \% と仮定していたアンテナ効率も $65 \%$ 前後に向上し ていて, $1 \mathrm{~m}$ 以下の直径でも良好な受信状態が確保で きるようになっている.

家庭用受信機は 10 社を越えるメーカーから市販さ れている，その性能の詳細は今後の調査を待つ必要が あるが，実用上ほぼ満足できる性能が得られていると 考えられる．価格は現時点では割高となっているが, 衛星放送の普及につれ，いつそうの低価格化が図られ るものと期待する。

(昭和 59 年 6 月 12 日受付) 


\section{〔参 考 文 献〕}

1）平田, 渡辺：“衛星放送受信機”, テレビ誌， $38 ， 3$, pp. 198 -206（Mar., 1984）

2）福地, 古津, 伊藤, 村上：“降雨減衰と電波伝搬”, テレビ 誌, 36, 4, pp. 294-300 (Apr., 1982)

3）衛星放送受信技術調査会：“調査会報告書一衛星放送受信機 （その 1 目標定格）“，電波技術協会（June, 1983）

4）衛星放送受信技術調査会：“調査会報告書一衛星放送受信機 （その 2 望ましい性能)”, 電波技術協会 (Sep., 1983)

5）衛星放送受信技術調查会：“調查会報告書一衛星放送受信機 （その 3 試験方法)”，電波技術協会（Sep., 1983）

6) NHK 編：“衛星放送の受信入門”, 日本放送出版協会
(1959)

7）衛星放送 CATV 技術調查会：“衛星放送 CATV 技術調查 会報告書（衛星放送 CATV 技術Part 1)”, 電波技術協会 (Feb., 1984)

8）笠木, 長尾, 北川, 大野, 平田：“衛星放送受信機用音声信 号処理回路 IC の開発”, テレビ学技報, RE 83-39, pp. 1-6 (Oct., 1983)

9）根津, 原田, 福井：“衛星放送用 PCM 音声復調 IC”, テレ ビ学技報, TEBS $97-2$, pp. 7-12（June, 1984）

10）宮沢，田村，近江，須崎：“衛星放送受信信号の有線伝送に おける反射の影響”，テレビ学技報, RE 83-42, pp. 19-24 (Oct., 1983)

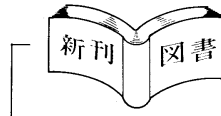

\section{電気学会大学講座}

\section{光と画像の基礎工学}

\section{社団法人電気学会編 \\ 金出武雄，栗田正一，坂出利之， 高梨裕文，山口昌一郎 著}

半導体素子を中心とした電子デバイスやコンピュー ター技術の発展に伴い, 光学画像処理技術も着実な進 歩をとげている.

本書は, 電気学会大学講座シリーズの 1 編をなすも ので, 光エレクトロニクス理論 $\rightarrow$ 光機能素子 $\rightarrow$ 画像処 理システムを統一して理解するためのニューメディア 時代における学生, 技術者必読の入門書, と銘打たれ ている.

光物性, 光電変換素子, 画像処理の分野をそれぞれ 単体で取り上げた本はかなり見受けられるが，これら を関連づけて統一的にまとめた本はめずらしい．

新たに光学情報処理に取り組もうという人にとうて は格好の入門書と言えるだろう。

内容は，第 1 編と第 2 編に分かれ，第 1 編が「光工 レクトロニクス」, 第 2 編が「画像処理の基礎」となっ ている.
第 1 編は， 1 章の「光波の基本的性質」に始まり，2 章「光放射」, 3 章「光波の伝搬」, 4 章「光による物質 の応答」, 5 章「光機能素子」, 6 章「光学情報処理」, 7 章「光と色の表示」と続く.

第 2 編は， 8 章の「画像情報理論」，9 章の「画像処 理技術」, 10 章の「画像処理システム」, 11 章の「シー ンの認識と理解」によって構成されている.

全編にわたり基礎的なことが系統だてて述べられて おり，非常にわかり易い点が読者にとってありがた い.

本書は, 光学的な基礎理論から画像処理システムに 至るまで広範囲の分野を取り上げているが，どちらか というと第 1 編の光エレクトロニクスに関して詳しい 記述がなされ，画像処理はごく基本的な部分に絞られ ている.

しかし, 光は単に画像処理のものだけでなく, 画像 工学全体の基盤となる物理現象であることを考えると 当然かとも思える。

なお，画像処理を本格的に始める人にとっても，絶 好の入門書と言える.

紹介 佐藤和弘（日立）

オーム社刊（昭和 59 年 4 月発行）, A 5 判, 定価 3,400 円 